\title{
País de Sonho e Encantamento: (Dis)Enchantment in Postcolonial ImAGinings OF THE CONTEMPORARY (LUSOPHONE) WORLD
}

Anthony Soares

Centre for Cross Border Studies, Armagh, Northern Ireland ${ }^{1}$

\begin{abstract}
This paper questions the extent to which current critical engagements with postcolonial realities may exhibit an exoticising tendency they simultaneously decry as colonialism's orientalist reflex. Contemporary instances of the exoticization of the "other", however, are not necessarily the result of a practice of cultural translation that becomes 'the superimposition of a dominant way of seeing, speaking and thinking onto marginalised peoples and the cultural artefacts they produce' (Huggan, A Postcolonial Exotic 24). Instead, it is proposed they result from a reaction to a localized political disenchantment that leads to an imagining of a postcolonial distanced "other" portrayed as the possibility of resistance to the hegemonic forces bemoaned by the postcolonial critic. Is it legitimate, therefore, to ask whether the exoticizing essence of the description of Portuguese Timor in the 1930s by the deportado Paulo Braga as 'Um pais onde é belo e doce viver' survives as an undercurrent in analyses of postcolonial Timor-Leste?
\end{abstract}

Keywords: East Timor, Paulo Braga, Luís Cardoso, postcolonial criticism

The overall purpose of this essay is to explore the extent to which current critical engagements with "Lusophone" postcolonial realities may exhibit an "exoticising" tendency they simultaneously decry as colonialism's orientalist reflex. Contemporary instances of the exoticization of the "other", however, are not necessarily always the result of a premeditated practice of cultural translation that becomes, as Graham Huggan (2002: 24) has suggested, "the superimposition of a dominant way of seeing, speaking and thinking onto marginalised peoples and the cultural artefacts they produce". Instead, I argue they result from a reaction to a localized political disenchantment that leads to an imagining of a postcolonial distanced "other" portrayed as the possibility of resistance to the hegemonic forces bemoaned by the postcolonial critic. It is in this act of imagining that we run the risk of the "Lusophone" becoming a multi-polar

1 Email: a.soares@qub.ac.uk. I would like to offer my sincere gratitude to the anonymous reviewers of this text for their insightful criticisms of an earlier draft, and to the editors for their helpful suggestions. 
site of "shared difference" - it becomes a label that looks to unite various parts of the former Portuguese empire under an understanding that they all differ in similar ways to the rest of the postcolonial world that surrounds them. This occurs not only in terms of a history - or histories - of colonialism that, as has been pointed out so often, cannot be properly understood through the application of frameworks developed in the light of other colonial spaces (such as the British or French colonial empires). Indeed, this issue has been examined in detail, for example, by Boaventura de Sousa Santos in his 2002 essay, "Entre Próspero e Caliban: colonialismo, pós-colonialismo e inter-identidade" (with an English version published in the same year as "Between Prospero and Caliban: Colonialism, Postcolonialism and Inter-identity"), while the question of the "Lusophone" and of lusofonia has been problematized over several decades by Eduardo Lourenço, and synthesized in the essays published in Nau de Ícaro seguido de Imagem e Miragem da Lusofonia.

Speaking of the "arquipélago descentrado na carta do mundo em que o português como língua, cultura e ficção também de si se descentrou para se perpetuar como o outro e o mesmo”, in his unique way Lourenço (1999: 111) points to the risks inherent in the tendency to solidify a "Lusophone" world that is always "decentred". Accordingly, it is as a visual reminder of the permanently decentred nature of the notion of the "Lusophone" that this term appears here in inverted commas, suspicious of uncritical interpretations or its translation into a political rhetoric that distorts the history of Portuguese colonialism and its reincarnation in the postcolonial world. In this case, the "Lusophone postcolonial" world can be interpreted as a reality thanks to a vision of Portuguese colonialism that, according to the circumstances and political objectives, confers on it effects in the present that are translated as a "Lusophone" identity that unites the peoples of Portugal and its former colonies, but which a decentred colonialism would have found difficult to produce during the period of colonial rule itself. Alternatively, this vision exploits the plasticity of that colonialism and its lack of a centre in order - in the context of the CPLP- to allow the entry of an Equatorial Guinea into a community whose "Lusophone" identity can in this case encompass something we would think was contrary to the values of that same community (although, it is important to stress that the CPLP is not the direct equivalent of the "Lusophone", even if the latter is always underlying the foundations of the former). The difference of the "Lusophone postcolonial" gains legitimacy within a context read as being the result of a colonialism that was itself "different", and of colonial practices (such as the emphasis placed on control of maritime trading routes rather than on wholesale territorial occupation and the establishment of colonial authority, which only occurred towards the end of Portuguese colonial rule) that did not require homogeneity in its colonies. Or, perhaps it would be more accurate to say that it was the result of a colonialism whose implementation was unable to entirely supplant indigenous belief systems or social hierarchies in order to introduce a common religion or a single model of social organization, leading to a range of different (post) colonial societies in the Portuguese colonial space.

However, it is also not simply the case that a Lusophone commonality of difference implies postcolonial realities that bear the stamp of difference imparted by that "different" history of Portuguese colonialism. The danger that must be avoided is the willed vision of Lusophone difference that is unconsciously shrouding a sameness - a sameness constituted by that very notion of the "Lusophone" - against which an unknowing army of cultural producers is being enlisted. What emerges here as an apparent contradiction between "willed" and "unconscious" is the result of what I consider a more deliberate propensity to highlight differences (constituted, for example, by cultural affinities in the Portuguese-speaking world that are not seen as existing 
to the same degree in other former colonial spaces) that simultaneously reinforce the idea of the Lusophone and make it appealing to a wider audience. But this is done to avoid a political reality without necessarily recognising that this is why the Lusophone is being trumpeted. The work of writers and artists from the "Lusophone" postcolonial world becomes the canvas onto which the postcolonial critic paints an anti-hegemonic slogan that is not necessarily in tune with that onto which it is overlaid. I will attempt to illustrate what I mean by turning (once again) to Timor-Leste, looking first at Portuguese political exile Paulo Braga's impressions of the territory in the 1930s, before examining some critical engagements with East Timorese postcolonial literature.

However, it is important to note from the outset that although literary works about or from Timor-Leste are objects of analysis in this essay, what concerns us here are the critical readings of that literature and what they might imply. I do not intend to impose any limits or obligations on East Timorese literature (or any other literature), which would run counter to literary creativity. Equally, I register here the fact that what follows does not claim to have an objectivity free from preconceived ends. My approach to the application of postcolonial criticism to literary production follows the sentiments expressed by Neil Lazarus:

I have been emphasising the registration of the specifically capitalist dimensions of the colonial experience, across the full range of "postcolonial" literature, in order to draw attention to the fact that postcolonial criticism, as an institutionalised mode of academic practice, has tended to turn a blind eye to what this body of literature has notably been concerned to put on display. The gap or disjuncture between the purviews of "literature" and "criticism" here is no cause for celebration, in my view. I see it as telling decisively against postcolonial criticism, testifying both to its abstraction and to the tenuousness of its grasp of the central realities of life in the "postcolonial” world (2011: 14).

I would add that some postcolonial criticism does not only ignore those capitalist dimensions in its analysis of postcolonial literature, but also in some of the literature produced during the colonial period, thus not giving sufficient visibility to the link that draws together the colonial past to the postcolonial present. This allows the latter to continue to repeat some of the former's sins, even if they present themselves in ways that suggest a rupture between the colonial and its "post". The postcolonial criticism that follows this vein is that which weaves theories based on an abstraction, priding itself in an objectivity in which an ideological oppositional positioning made visible by the critic does not conform with an institutionalised academic practice. The result, in this case, is a postcolonial present forgetful of the political-economic system that did so much to create it in the colonial past. It is, therefore, by returning to that past that we begin our analysis.

Born in 1905 in Vila Real de Trás-os-Montes, and exiled to Timor for his socialist beliefs from 1931 to 1933, Paulo Braga's published accounts of his time in Timor are clearly suffused with an exoticising tendency. Indeed, this is recognised in Rui Brito da Fonseca's introductory notes to Braga's text, as he refers to the 'subjectividade própria de uma visão romântica, mesmo poética' evident in País de Sonho e Encantamento (2006: 7). Notwithstanding the romanticised vision arising from Braga's subjectivity in what had originally been five separate essays, appearing between 1935 and 1937 in the journal Cadernos Coloniais, Brito da Fonseca judges them worthy of republication as a single text in Timor-Leste in 2006, with the support of several Portuguese institutions. Arguably, this editorial initiative in postcolonial Timor-Leste could 
be interpreted as a repetition of the colonial past, in that the texts appearing in the Cadernos Coloniais, although ostensibly concerning Portugal's colonies, were as much about the reinforcement of an inherently fragile image of Portugal as the centre of an empire. The republication of Braga's narrative could be seen as a Portuguese claim for a central role in the edification of a postcolonial nation with cultural ties to its former colonial ruler. The result is the opportunity for a new generation of readers to become acquainted with an account that from the outset portrays the Portuguese colony as a veritable Eden:

Timor é um país de sonho e encantamento, perdido em planícies verdejantes e montanhas floridas [...].Por toda a parte, sinfonias de cores, sinfonias loucas de perfumes, como nos arco-íris, como nos templos budistas. Depois, uma natureza primitiva - onde tudo é inédito, onde tudo é diferente. O instinto dominando as convenções, a verdade genésica ainda vitoriosa ante os preconceitos (12-13).

However, into this Edenic landscape filled with luxuriant colour and aromas have come Europeans and with them a new way of life that cannot contemplate a society where "se vive de qualquer forma quando não se têm grandes aspirações e se tem tudo quanto se deseja sem penoso esforço para o adquirir" (17). And so:

entretanto, quase sem se sentir, tudo vai sendo diferente do que foi outrora. O europeu, ao colonizar, quer que os indígenas tenham as suas casas e as suas hortas e mobiliza-os para abrir e conservar estradas, para os carregamentos, para o serviço militar [...]. Leva-os a desejar um pouco de luxo, de riqueza, de comodidade e civilização. Exige-lhes o imposto (17).

The forced imposition of a socio-economic order that will usher in a particularly oppressive - because colonialist - form of capitalism, with its emphasis on private accumulation of wealth and its attendant modes of production, will condemn indigenous forms of being whose loss appear to be bemoaned by the Portuguese exile. Having been led to "desejar um pouco de luxo, de riqueza", the East Timorese are converted into consumers - but always enacting a consumerism that confirms their subjection and reinforces the position of power of the colonizer. This condition is made visible on several occasions in Braga's accounts as he remarks on the sad figures of Timorese women dressed in poor copies of the clothes and accessories worn by Europeans.

Instead, for Paulo Braga the inhabitants of the small island of Ataúro, lying off the northern Timorese coast within a short distance of the capital, Díli, become the epitome of a society that - whilst it is able to resist the most pronounced effects of colonialism - has much to commend it. In what Braga calls "a ilha da gente nua", the "organização social timorense, de feição capitalista e religiosa, influiu, já obliterada, [...] sem criar raízes e se diluiu numa perfeita organização comunista" (140). Crucially, a distinction is made between a Timorese social organisation and how society is organised on Ataúro. In this construction, what is "Timorese" is already and irreparably shaped by capitalist and Catholic features but, since these were brought by a colonizing nation unable to enforce its will unconditionally, the "Timorese" influence is too weak to transform society on Ataúro into a community of submissive consumers of goods and religious rituals imported from Portugal. What results instead is a society that, in contact with diluted forms of capitalism and religious organisation, emerges in the eyes of Paulo Braga as a communistic social formation. Consequently, on Ataúro "A terra é de todos. Pertence a quem trabalhe nela, quando nela quiser trabalhar" (138). Given these indigenous relations to labour and the land the native population "não compreende as atitudes dos homens da sociedade diferente da sua, que exploram esse trabalho", so that "na sua alma deve surgir emocional a revolta contra a civilização" (146). When the intensity of the colonizing impetus is increased on Ataúro, becom- 
ing less diluted in terms of its desire to impose more markedly capitalist-colonialist modes of production, the attendant risk of native resistance increases as well. Indeed, appearing at regular intervals in Braga's accounts are references to native resistance that convey the author's admiration for attempts to reject the civilizing efforts of the Portuguese, as when he states "penso nas guerras de Timor, nas ameaças sempre latentes de chacina total dos europeus, no espírito aguerrido dos indígenas" (64-65). Yet, given that these attempts belong to the past, Braga also conveys the sense that he is mourning the success of the Portuguese pacification campaigns, which have left "duzentos ou trezentos mil guerreiros em paz" (65).

However, the undercurrent of regret in Braga's accounts of his time in Portuguese Timor, as well as the numerous passages that offer an Edenic landscape existing "lá para os confins do Oriente" (14), do not constitute any sort of general indictment of a colonizing effort that is condemning noble indigenous traditions to extinction. As Madalena Ceppas Barreto (2012) and others have noted, Paulo Braga was not criticising the idea of colonialism, but rather the specific nature of Portugal's colonizing efforts in its Timorese colony. Due to its many deficiencies Portuguese colonial rule encouraged the emergence of a native population infected by all the worst vices of its colonial masters and none of their putative virtues. The absence of the latter not only does not mitigate the existence of the former, but also ensures the survival of those vices seen as "natural" to the Timorese, and most often embodied by native women in Braga's narrative. Braga reacts with repugnance when faced with evidence of an indegeneity stripped of any vestiges of what could have once been considered "noble", leaving only a deformed native population described on one occasion as an "estendal de podridões físicas e mentais, elevando cheiros nauseabundos, rindo em esgares terrificantes, um grand-guignol triste e desolador que nos enche a alma de desesperança" (83). What we are left with is a mixture of repulsion and attraction, both of which result in an "othering" of the Timorese that leaves them exotically distant, at once impossibly edenic and irrevocably savage.

In Braga's eyes hope rests in the transformation of the colonial presence from one based on a parasitical and oppressive exploitation of the native's labour that leaves him in a continuing state of savage misery, to one that would bring modernity and equality through a genuine "civilizing" mission. Instead of a landscape where one could come across "um forte desmantelado, um túmulo com uma cruz, um europeu, que recebe o imposto, um comerciante chinês que explora os vícios da miséria e um forno de cal onde trabalha a gente nua" (128), a renewed colonial activity centred on the territory's coffee cultivation would mean that "Um mundo de beleza dará lugar a um outro mundo, também belo e mais prometedor de felicidade para os homens" (197). In this new world,

um tempo há-de vir em que o trabalho não será [...] um sacrifício, em que o trabalhador não será um escravo para se explorar, recenseado nos postos para ser sentinela nas plantações contra o ataque da selva. As plantações ficarão ao serviço da colonização. E quinhentos mil timorenses serão quinhentos mil trabalhadores e produtores. O comerciante, chinês ou europeu, terá desaparecido (197).

This future idyll, located in a luxuriant island paradise corresponds in crucial ways with Edward Said's conception of the Orientalist tendency to create a fiction of the Orient in order to support an equally fictional West, but one where Occidental superiority is always assured. However, Paulo Braga's recollections of Timor differ, perhaps, in the relationship between bis West (Portugal) and his Orient (Portuguese Timor), in that the latter could be seen as possessing the potential to supersede the West by adopting a socialist or communist political system that did not exist in Portugal, and thus transforming it into "um país ideal no mundo" (197). 
Crucially, Braga's assessments and opinions of Timor are inextricably located in Portugal and driven by a political landscape that is not really to be found in the Portuguese colony but in the metropole. His moments of revulsion by what he encounters in Timor are, in my view, provoked by instances of what he considers to be a native surrender to predatory capitalist forces. Meanwhile, Braga's praise is reserved for indigenous traits he regards as being in line with his own socialist beliefs, betraying the fact that "the native" and "the indigenous" are products of a colonialist vision that will remain an obstacle to any possibility for genuine dialogue between colonizer and colonized (if it is ever sought). Both reactions, however, lead to a narrative that elides the basic fact that what the native population of Timor is being simultaneously and unjustly blamed and praised for is the inability of those who inhabit the centres from which colonialism is emanating to overturn their own political situation. In other words, in Braga's narratives the forcibly adopted Timorese sons and daughters are paying the price for the sins of the colonialist-capitalist fathers since their "natural" progeny are unable or unwilling to challenge a parental rule they recognise as oppressive. However, the very differing degrees to which the inhabitants of the colony and those of the metropole feel that oppression are also extremely significant. They contribute to how Braga experiences Timor and explain why the rule of the colonial father is not seriously challenged in the "mother" country.

An almost incidental event in Braga's text illustrates why I am suggesting that, whatever the criticisms of Portugal's colonial practices in Timor, there is an underlying sense that the "benefits" of colonialism will not be easily surrendered by those who are its beneficiaries and, consequently, that there will be no attempt to overturn a regime based on the idea of an imperial identity that produces those "benefits". Recalling one of his treks into the heart of the Timorese countryside, Braga describes coming upon what appears to be an abandoned Portuguese outpost where, in his words, "a minha atenção dirige-se para um telefone que, ao canto duma sala do presídio, é um símbolo do progresso na selva timorense" (65). Indications in the wilderness of the Timorese landscape of a technological modernity comfort Braga who sees them as beacons of hope, although he ignores the possibility that they are directly or indirectly products of colonial exploitation. They are also symbols of a leisurely life that those who benefit from colonialism are reluctant to give up, whilst those who are its victims are unlikely to ever possess since they have no similar moments of leisure. The colonized also become the unwilling enablers of the leisured lives of the colonizers because their toil relieves their colonial masters of the need to work. Indeed, Braga is conscious of his own attachment to the comforts associated with "civilization" and "modernity", and remarks:

\footnotetext{
Entretanto, neste mundo que vivi durante algum tempo, a vida nem sempre foi um pesadelo. Encontrei estradas, telefones, automóveis, grafonolas, rádios e livros... Um alfaiate fez-me os fatos brancos e um china miserável vendeu-me sapatos de borracha e um capacete made in Xangai. Tinha casa, cadeiras, um leito... A paisagem e a existência selvagem, brutal, visionei-as quando as procurava o meu ideal desportivista de caminheiro ou de turista. $\mathrm{O}$ resto, era vida civilizada, vida vivida à europeia nestes confins misteriosos do Oriente (21).
}

Braga's self-confessed experience of the Timorese "existência selvagem" is packaged as a consumerist journey through the landscape that could only be made possible through a "vida vivida à europeia" whose "Europeanness" is constructed on the backs of the colonized. Unless this link is fully acknowledged and those like Braga denounce all forms of colonialism and are willing to relinquish the benefits it brings them, then there is little hope not only that an unjust regime will be overturned in dictatorial Portugal, but also that Timor could ever become "um país ideal no mundo". 
Indeed, I would argue that a similar attitude endures in terms of the critical reception of contemporary East Timorese literary production, and more specifically of the work of the novelist Luís Cardoso. The continuing reluctance to assume the full consequences of the political structures that exist in certain parts of the globe impel some critics to look at today's "confins misteriosos do Oriente" in ways that are reminiscent of Paulo Braga's outlook in the 1930s. What I am suggesting is that interpretations of Luís Cardoso's fiction - which has conspicuously become a metonymic symbol of East Timorese literature - may be tainted by reactions to a political configuration that becomes the ultimate object of the critic. Indeed, this possibility takes on another dimension within a "Lusophone Postcolonial" perspective - one that is, of course, intensely problematic in terms of its configuration. Whilst not with the literary in mind, Miguel Vale de Almeida's reflections on the reaction in Portugal to the violent events that took place in Timor-Leste in 1999 point to what I am thinking of here. Almeida (2004: xi), in view of the significant and very visible demonstrations of support that occurred in the Portuguese capital and elsewhere, suggests that "The social movement of solidarity with East Timor that occurred in Lisbon in September 1999 demonstrated the importance to the Portuguese of emotional and cultural ties to people whom they saw as sharing their language and religion". What are seen as common linguistic and religious markers become essential components of the notion of a Lusofonia that, in turn, Almeida (2004: xi) claims to form "the core of a Portuguese postcolonial identity" - although I would perhaps go further, and suggest that this identity is not necessarily only to be found within Portugal's borders, and that other CPLP nations may from time to time promote a "Lusophone" identity when it may be found convenient to do so. This process of identification is made possible by the "colonial register" as it is conceived by Kelly Cristiane da Silva (2012: 153), which leads to practices that are "expressivas de uma maneira de performatizar [...] expectativas em relação à posição do outro, criadas por referência a uma experiência histórica de colonização", and where that register "delimita o que pode ser visto, ouvido, pensado e dito sobre esse outro, caracterizado normalmente como uma projeção de si mesmo".

Nevertheless, and having already remarked that the "construction of the notion of a special bond between East Timor and Portugal [...] was only possible on the basis of selective forgetting (of both [...] rebellions and the anticolonial movement)" (2004: 91), it is with what is found within the Portuguese borders in mind that Almeida offers the following comments by way of a conclusion:

During the events of September 1999, the Portuguese imagined East Timor. Its small size, its distance, the existence of a big, dictatorial, and Muslim enemy (Indonesia), and the denunciation of an unjust international order in which the strong (the United States) fail to protect the weak were the narrative elements for the construction of a mythical place (99).

Although these comments raise a number of interesting implications, I would like to focus here on the idea of an "imagining" of Timor-Leste that seeks to counter "an unjust international order" seen as hegemonic. While reactions in some quarters to the violence that followed the 1999 referendum was, in my view, based to some extent on the opinion that "the West" was deliberately neglecting the suffering of the East Timorese, the subsequent formal emergence of Timor-Leste as an independent nation in 2002 was imbued by some (and I would include myself amongst them) with the hope that it would represent an alternative model of nationhood - and a Lusophone one at that, countering a world-system with a distinctly Anglophone flavour... but where the "Anglophone" and the "Lusophone" are ultimately oppositional fictions. Such hopes may have been fuelled further by the fact that its first government was formed by 
FRETILIN, a political party whose rhetoric still contained calls for genuine social justice, and one that entered into negotiations with its powerful Australian neighbours over the exploration of oil and gas in the Timor Sea fully prepared to demand its rights. Here we had the opportunity to cast the East Timorese as taking up the rhetorical arms against the Antipodean bulwark of the hegemonic world order, and offering a glimpse of the possibility of an alternative - an island of hope in a sea of political conformity. In this sense, what was happening in the postcolonial context was a repetition of the construction of a certain Timor undertaken by Paulo Braga in the 1930s, where the underlying object of critical attention was not the half-island nation itself, but rather the observers' unsatisfied need for a radical socio-political change at home.

And yet, perhaps the reason for this dissatisfaction stems in part from a reluctance to fully assume and be identified with the radicalism that would presumably be necessary to bring about change. Indeed, in a recent essay Régis Debray (2013: 39) comments on the discomfort felt by many Europeans when faced with the reality of those who are willing to make the ultimate sacrifice to bring about the change necessary for them to achieve nationhood:

In Europe, the notion - in fact, the sentiment - of national honour provokes smiles of pity or stupefaction in two out of three under-50s. [...] For an emancipated post-national, a denizen of some postmodern Left Bank who sees the nation-state as a museum piece or a joke, the idea that some fifty peoples are prepared to fight to have one indicates a pathetic infantilism.

This type of attitude that eschews radical positions could begin to explain why Luís Cardoso's fiction has gained a considerable critical audience. Cardoso has resided in Portugal since he went there to study, and where he found himself when his country was invaded in 1975. A central feature of his work is a sense of discomfort similar to that expressed by some of his narrators when faced with those East Timorese fully engaged in the struggle against the Indonesian occupation, as can be seen in his 1997 debut novel, Crónica de uma travessia. In this case, not only does the narrator suggest the constructed and hence always dubious nature of an East Timorese national identity (personified in the figure of the Maubere) for which a bitter struggle is being fought, but he also confesses to his unease when he is called to confront the human sacrifices being made in the name of independence. These were found in the area in Lisbon where East Timorese refugees were housed following the Indonesian invasion, and of which the narrator states: "Em boa verdade eu temia aproximar-me do vale do Jamor. Eles tinham visto a morte vermelha, matada e morrida" (115). His fear is that by facing these refugees he will be forced to acknowledge the ultimate consequences others are prepared to incur by being identified as belonging to one side of an antagonistic binary, and therefore to be reminded of his own refusal to wholeheartedly join a communal struggle whose final objective he may in fact desire. It is a reluctance that regards the loss of individual freedom inherent in adhering to a common cause as somehow counterproductive because it is supposedly a cause that seeks to achieve precisely that - freedom. This "Cardosian" hesitation could also, therefore, appeal to a certain readership as it suggests the search for an alternative to a binary conception of reality that will always breed conflict and oppression. ${ }^{2}$

2 A possible alternative in the context of political responses to the devastating effects of the recent global (?) financial crisis is proposed by Nancy Fraser (2013: 129) in what she calls a "triple movement". This corresponds to "a three-sided conflict among proponents of marketization, adherents of social protection and partisans of emancipation" (129). The coming together of the two latter poles of this conflict represent the hope of overcoming the other one, thereby defeating the forces of neo-liberalism without losing the individual freedoms that may have been at risk by the unilateral victory of the proponents of social protection. For Fraser, a "double movement" formed by a "counter-hegemonic project aimed at protecting society and nature from neoliberalism" (122) is undesirable given 
Above all, however, what I see as the primary pole of attraction in Luís Cardoso's work - and something that is perhaps not evident in other East Timorese writers who, through concerns over what they see as increasing foreign influences, privilege elements considered to be indigenous - is the idea of multiple origins. In all of his five novels to date, the half-island of Timor is the site of constant arrivals and departures, many of which ultimately contribute to a culture and an identity that are apt to be understood as perfect examples of a postcolonial hybridity that is to be welcomed as counteracting calls for identitary purity that are dangerously exclusionary. Moreover, it is a hybridity in which, according to Cardoso's most recent novel, O ano em que Pigafetta completou a circum-navegação (2013: 186), "há sempre português metido pelo meio", apparently reminding us of the elements we noted earlier in Miguel Vale de Almeida's observations regarding the Portuguese capacity for imagining a Timor that is in many respects an extension of Portugal, although I would suggest it is a trait not exclusive to the Portuguese.

Thus, it is to Cardoso's Requiem para o navegador solitário (2007) that José Luís Giovanoni Fornos turns to in his essay on the contribution of postcolonial studies to comparative literature. Fornos (2011: 30) claims that Requiem represents an example of "Uma nova consciência geográfica descentrada" that is "fruto do colonialismo, das migrações, das deportações, dos êxodos e exílios, da presença de viajantes e aventureiros" (31). Having focused specifically on how "as personagens compõem-se quase sempre de uma formação cultural híbrida em que despontam, conjuntamente, valores ocidentais e orientais" (31), Fornos concludes his essay by including Cardoso's novel as an example of "produções culturais polifônicas como expressão de um novo capital mundial" (33) that undercut the forces of free-market fundamentalism. Similarly, Anselmo Peres Alós employs Cardoso in his discussion of Lília Momplé and the role of cultural memory and the postcolonial imaginary in forming a Mozambican literary identity. In his introductory comments, Alós (2011: 139-140) turns to a date that we are already familiar with to pose some significant questions:

É de sintomática importância [...] o ano de 1999: de um lado, a União Européia adota uma moeda única, em sintonia com os processos de globalização da economia e da circulação do capital (inclusive cultural); de outro, Timor Leste, depois de mais de vinte anos de ocupação indonésia, finalmente alcança sua independência política. Estar-se-ia vivendo um período de "globalização do imaginário", correlativo à globalização do capital econômico e das relações internacionais? Ou será que a literatura, na contramão da globalização econômica do planeta, estaria a funcionar como um processo simbólico e discursivo que, a contrapelo da homogeneização cultural, insiste no caráter irredutível da diferença como capital cultural fundamental na economia das relações humanas?

What I would like to suggest by way of a conclusion is that there is a risk that critical readings of contemporary East Timorese literature may embed exoticised notions of TimorLeste that belong to what Alós (2011: 141) terms the "imaginário pós-colonial lusófono". This "Lusophone postcolonial imaginary" will travel to a Timor-Leste that is a fiction in order to fight the hegemonic forces that emanate from elsewhere, finding a Lusophone difference an exceptionality - to raise as a banner of defiance against a "West" that is perhaps unfairly characterised as essentially Anglophone, and whose precise limits are rarely made explicit. In

that it would result in the replacement of neoliberalism by another socially limiting force.

3 I am very conscious that (beyond Fornos, perhaps) I am not pointing to any specific examples of such readings. However, I believe that what is of paramount importance is our awareness of the possibility that exoticised notions of East Timorese literature may emerge intermittently in critical readings that are otherwise sensitive to this issue, as well as in others that may be oblivious to their exoticisation. Nevertheless, if an example is required, then see my essay, "Liberating East Timorese Liberation Poetry: Oppositional Discourses and Postcolonial Theory". 
this act, readers (Portuguese?) in the "West" turn the pages of an East Timorese (Angolan, Mozambican) novel and are comforted by evidence of a post-Lusotropical-like identity that points to the survival of a way of being in the world seemingly under threat.

Conversely, when those same novels speak of the infiltration of hegemonic values into the former Portuguese colonies, feelings of righteous indignation are aroused along with the barely suppressed will to cry out for those who live in these postcolonial nations to resist. All the time, however, the reader (and more importantly, the postcolonial critic) does little or nothing to undermine the exploitative forces of hegemony at the sites from which they originate, and instead becomes complicit in the act of what Nancy Fraser (2013: 131-132) describes as "abandoning the billions across the globe who rightly understand that there is something worse than being exploited - namely, being counted as not worth exploiting". ${ }^{4}$ We need to be attentive to elements in the contemporary literary production of Timor-Leste and elsewhere in the space of the former Portuguese empire that run counter to the idea of a postcolonial "Lusophone" or "post-Lusotropical" identity, and that celebrate to a greater or lesser extent the currents of globalization that some who have enjoyed their benefits wish to decry in other contexts. The poet Abé Barreto, for example, opens his poem in Tetum "Homan ami-nia Futuru" (Weaving Our Future) with the cry "Hasa'e bandeira Luzofonia nian iha rai ida-ne'e" (Take down Lusofonia's flag from this place), while in "Proklamasaun Independénsia" (Proclamation of Independence) he declares: "Ba mundu tomak ita hakilar/Ba mundu tomak haklalak/Ba mundu tomak ita tebe-rai://Rai ne'e ami-nian, la'ós imi-nian!" (We cry to the whole world/To the whole world we declare/To the whole world we affirm: "This land is ours, not yours!"). ${ }^{5}$ By being attentive to such presences we will avoid creating 'um país de sonho e encantamento' that is the product of a real disenchantment we would rather not face up to ourselves, preferring instead to enlist some postcolonial landins we insist on finding in the pages of a Luís Cardoso. ${ }^{6}$

\section{Works Cited}

Almeida, Miguel Vale de. 2004. An Earth-Colored Sea: "Race", Culture and the Politics of Identity in the Post-Colonial Portuguese-Speaking World. New York and Oxford: Berghahn Books.

Alós, Anselmo Peres. 2011. "Memória cultural e imaginário pós-colonial: o lugar de Lília Momplé na literatura moçambicana." Caligrama 16 (1): 137-158.

Barreto, Abé. 2010. "Proklamasaun Independénsia." In Lia Murak - Lia Midar - Lia Matak

Malirin. Retrieved 30 July, 2014. (http://lianainlorosae.blogspot.co.uk/2010_12_01_archive.html).

2009. "Homan ami-nia Futuru." In In Lia Murak - Lia Midar - Lia Matak Malirin.

Retrieved 1 August, 2014. (http://lianainlorosae.blogspot.co.uk/2009_01_01_archive. html).

4 What Fraser is pointing to here is the temptation to deny the possible freedoms offered by the market through its wholesale replacement by a system of social protectionism that suffocates individual liberties.

5 Much of Abé Barreto's work is to be found dispersed on the Internet, where the poet has three blogs: one with poems in Tetum, another with texts in English, and the other with works in Bahasa Indonesia.

6 Landins was the generic term used by the Portuguese to refer to the Mozambican natives to the south of the river Save. They were considered to be fierce warriors, and were used by the Portuguese in wars of "pacification" in other colonies, including Timor. 
Barreto, Madalena Ceppas. 2012. "Paulo Braga." In History and Anthropology of "Portuguese Timor”, 1850-1975, edited by Ricardo Roque. Retrieved August 23, 2014 (http://www. historyanthropologytimor.org).

Braga, Paulo. 2006. País de Sonho e encantamento: Timor 1930. Díli: Crocodilo Azul.

Cardoso, Luís. 2013. O ano em que Pigafetta completou a circum-navegação. Porto: Sextante. 2007. Requiem para o navegador solitário. Lisbon: D. Quixote. 1997. Crónica de uma travessia: A época do Ai-Dik-Funam. Lisbon: D. Quixote.

Debray, Régis. 2013. "Decline of the West?” New Left Review 80: 29-44.

Fonseca, Rui Brito da. 2006. "Introdução do editor." Pp. 7-8 in Paulo Braga, País de Sonho e encantamento: Timor 1930. Díli: Crocodilo Azul.

Fornos, José Luís Giovanoni. 2011. "Contribuição da Crítica Pós-Colonial aos Estudos de Literatura Comparada.” R. Lingua e Literatura. Frederico Westphalen 13 (20): 13-35.

Fraser, Nancy. 2013. "A Triple Movement? Parsing the Politics of Crisis after Polanyi." Nerw Left Review 81: 119-132.

Huggan, Graham. 2002. The Postcolonial Exotic: Marketing the Margins. London and New York: Routledge.

Lazarus, Neil. 2011. "What Postcolonial Theory Doesn't Say." Race E Class 53 (1): 3-27.

Lourenço, Eduardo. 1999. A Nau de Ícaro seguido de Imagem e Miragem da Lusofonia. Lisboa: Gradiva.

Santos, Boaventuda de Sousa. 2002. "Entre Próspero e Caliban: colonialismo, pós-colonialismo e inter-identidade." Pp.23-85 in Entre ser e estar. Raizes, percursos e discursos da identidade, edited by Maria Irene Ramalho and António Sousa Ribeiro. Porto: Afrontamento.

----. 2002. "Between Prospero and Caliban: Colonialism, Postcolonialism, and Inter-identity." Luso-Brazilian Review 39 (2): 9-43.

Silva, Kelly Cristiane da. 2012. As Naçôes Desunidas: Práticas da ONU e a estruturação do Estado em Timor-Leste. Belo Horizonte: UFMG.

Soares, Anthony. 2006. "Liberating East Timorese Liberation Poetry: Oppositional Discourses and Postcolonial Theory." Pp.159-175 in Postcolonial Theory and Lusophone Literatures, edited by Paulo de Medeiros. Utrecht: Portuguese Studies Center.

Date received: 2014-03-02

Date accepted: 2014-11-13 